\title{
注射剤調剤における疑義照会の解析
}

\author{
岩田政則*，久保田ひとみ，佐々木㻟也，縄田修一 \\ 横浜市立大学附属市民総合医療センター薬剤部
}

\section{Study on Inquiries Concerning Injectable Medicines}

\author{
Masanori Iwata*, Hitomi Kubota, Takuya Sasaki and Shuichi Nawata \\ Department of Pharmacy, Yokohama City University Medical Center
}

$\left[\begin{array}{l}\text { Received April 11, 2005 } \\ \text { Accepted July 10, } 2005\end{array}\right]$

\begin{abstract}
An injectable medicine dispensing system based on an auto ampule dispensing (AAD) system was introduced at Yokohama City University Medical Center. We made a drug interaction check list and a dose check list for pediatrics on which to base inquiries concerning prescriptions for injectable medicines for inpatients and over a three-year period, investigated the effectiveness of the inquiries and interventions resulting from them. There were a total of 865 inquiries and the number of inquiries increased 1.5-fold after residents were reassigned. Inquiries concerning dose accounted for approximately $66 \%$ of the total.

The number of inquiries for the five main clinical departments comprised $50 \%$ of the total number of inquiries. This suggests that careful instruction of residents before their reassignment to the main clinical departments is important. Inquiries were effective in avoiding adverse events for $64 \%$ of all adverse events. These inquiries were also effective in reducing medical expenses.

Inquiries concerning the injectable medicine dispensing system at Yokohama City University Medical Center based on a drug interaction check list and dose check list for pediatrics were therefore useful.
\end{abstract}

Key words — injectable medicine, injection dispensing, drug interaction, inquiry, dose check list, pediatrics

\section{緒 言}

注射剂は，薬物を直接体内へ投与することが可能であ ることから薬効の発現が確実である特徵を有する。一 方，誤って患者に投与した際には重大な結果をもたらす ことがある。近年, 注射剤による医療事故が増加傾向と なり, 薬剤師の積極的な関与が求められる環境にあるこ とから，注射剂調用 ${ }^{11}$ に関する多くの研究成果が報告 ${ }^{2,3)}$ されている。

著者ら ${ }^{4)}$ は, 当院の開院時に注射剂自動調剂システム を導入した新たな注射剤調剤システムを構築し，業務の 効率化を行った. さらに， $\mathrm{H}_{2}$ ブロッカーやプロトンポン プ阻害薬の注射剤をモデル薬剤として, 注射剤の適正使 用について疑義照会を行ったところ, 病院経営に対する 薬剂師の関与が認識され，処方医の関心も高まった5).

本研究では, 安全管理を中心に過去 3 年間の注射剂調 剂に関わる疑義照会を解析して，疑義照会と種々の情報
を積極的に他の医療従事者に提供したり，情報を共有化 する試みを行い, 経済効果も含めて検討した.

\section{実験 の 部}

\section{1. 調査期間および調査項目}

2001年 9 月より2004年 8 月 (36力月間)にわたり，疑義 照会を行った処方せんを調査した。調査項目は，月別 1 日あたりの平均入院患者数および，注射剂定時処方せん 枚数，疑義照会件数を測定した.さらに，物理化学的相 互作用や保険請求時に問題となる処方の疑義照会に関し て保険薬価で算定した金額を，2004年 3 月より8月まで の 6 カ月間にわたり調査した。

\section{2. 入院患者数および注射剤定時処方せん枚数}

休日，祭日を除く通常業務開始時における入院患者数 を，当院のオーダリングシステム (日本電気(株))より抽出 した。また，注射剤定時処方せん枚数を注射剂自動調剂 
システムより計測した。また，本システムの対象となら ない臨時処方や ICU 病棟や CCU 病棟などの特殊病棟や 救急関連病棟は計測から除外した．経時的な入院患者数 および注射剂定時処方せん枚数を検討するために単回帰 分析を実施した。

\section{3. 疑義照会データの収集と処理}

疑義照会ごとにその内容を「ファイルメーカーPro」 (ファイルメーカー(株) を用いてデータベース化した。主 な入力項目は，患者年齢，性別，診療科，処方医，疑義 照会分類，照会内容，成果分類，成果内容，薬剤費とし た。

\section{4. 疑義照会の内容}

疑義照会の内容を，投与量，用法，相互作用，同種薬 の併用，規格・保険適用，その他の 6 項目に分類した.

1) 投与量

投与量は，添付文書を参考にして鑑査，疑義照会を実 施した。また，小児投与量に関しては，当院の安全管理 室が主体となり，リスクマネージャーである薬剤師，小 児科医師，看護師が合同で簡易小览科投与量チェック表 （表 1 )を作成した。本チェック表では，患者の体重を5 $\mathrm{kg} ， 10 \mathrm{~kg} ， 15 \mathrm{~kg}$ に分類してそれに相当する投与量，投 与速度等の情報を表示した。新たな小児薬用量のチェッ クシステムの導入は，2003年10月 1 日からとした。2001 年 9 月 1 日より 2003 年 9 月 30 日までの 25 力月間を導入 前，2003年10月 1 日より 2004年 8 月31日の11力月間を導 入後として疑義照会の状況を比較した。また，処方の重 複入力例は投与量の項目に分類した。
2)用法

用法は，投与回数や投与時期が医師の指示と矛盾する 事例および希釈法，投与経路，点滴速度などが添付文書 と異なる事例を対象とした。

3 ) 相互作用

相互作用に関する成書 ${ }^{6)}$ と独自に作成した簡易相互作 用チェック表 $($ 表 2 )を鑑査時に使用して, 主に薬動力学 的相互作用と物理化学的相互作用を対象として鑑査を 行った。

\section{4 ）同種薬の併用}

処方された薬剤の薬効が同一または同種であり，明ら かに併用の必要がない事例などを対象とした。

5 ）規格・保険適用

処方された薬剤の含有量と，総投与量に対して安価な 規格がふさわしい場合やその最適な組み合わせに変更可 能な事例を対象とした。保険適用は，保険適用外使用に 関わる事例を対象とした。

6) その他

1 ) から 5 )に分類されない事例を対象とした。例とし て当院のオーダリングシステムに関わるもの，処方せん の区分，薬剤請求や搬送などに関わるものを対象とし た。

\section{5. 得られた成果}

疑義照会によって得られた成果を，「副作用などの有 害事象の回避」(副作用),「薬剂費の患者・病院負担の回 避」(薬剂費・保険)，「薬効減弱の回避」(薬効減弱)およ び「その他」に分類した。調査は2004年 3 月 1 日から 8 月31日までの 6 力月間にわたり行い，薬剤費の患者・病

表 1. 小児科用体重別投与量簡易チェック表(一部)

\begin{tabular}{|c|c|c|c|c|c|}
\hline 製品名 & 規格 & $5 \mathrm{~kg}$ & $10 \mathrm{~kg}$ & $15 \mathrm{~kg}$ & 重症量 \\
\hline アシクロビル注 & $250 \mathrm{mg}$ & $0.1-0.2$ A $/$ 日 & $0.2-0.4 \mathrm{~A} /$ 日 & $0.3-0.6 \mathrm{~A} / \mathrm{B}$ & $0.06 \mathrm{~A} / \mathrm{kg} / \mathrm{G}$ \\
\hline アタラックスP注射液 & $25 \mathrm{mg}$ & $0.2 \mathrm{~A} /$ 回 & $0.4 \mathrm{~A} /$ 回 & $0.6 \mathrm{~A} /$ 回 & \\
\hline アデホスしコーワ注 4 号 & $40 \mathrm{mg}$ & $0.025 \mathrm{~A} /$ 回 & $0.05 \mathrm{~A} /$ 回 & $0.075 \mathrm{~A} /$ 回 & $0.25 \mathrm{~A} /$ 回 \\
\hline アドナ注射液 & $25 \mathrm{mg}$ & $0.2 \mathrm{~A} / \mathrm{B}$ & $0.4 \mathrm{~A} / \mathrm{日}$ & $0.6 \mathrm{~A} / \mathrm{B}$ & $0.08 \mathrm{~A} / \mathrm{kg} /$ 日 \\
\hline アレビアチン注 & $250 \mathrm{mg}$ & 12 時間毎 & 0.04A/回 12 時間毎 & $0.06 \mathrm{~A} /$ 回 12 時間毎 & \\
\hline アンスロビンP & 500単位 & $0.2-0.6 \mathrm{~V} / \mathrm{B}$ & $0.4-1.2 \mathrm{~V} / \mathrm{\theta}$ & $0.6-1.8 \mathrm{~V} / \mathrm{B}$ & \\
\hline ウロキナーゼ注 & 60000 単位 & $0.833 \mathrm{~V} / \mathrm{日}$ & $1.67 \mathrm{~V} / \mathrm{B}$ & 2. $5 \mathrm{~V} / \mathrm{日}$ & \\
\hline \multirow[t]{2}{*}{ ヴェノグロブリン|H } & $500 \mathrm{mg}$ & （重症感染時） & （重症感染時） & （重症感染時） & (川崎病時) \\
\hline & $2500 \mathrm{mg}$ & $1000-2000 \mathrm{mg} /$ 日 3 日間 & $2000-4000 \mathrm{mg} /$ 日 3 日間 & $3000-6000 \mathrm{mg} /$ 日 3 日間 & $1-2 / \mathrm{kg} /$ 日 \\
\hline エスポー皮下用シリンジ & 750単位 & $0.67 \mathrm{~V} /$ 日 週2-3回 & $1.33 \mathrm{~V} /$ 日 & 週2-3回 & \\
\hline エポジン注シリンジ & 15001. U. & $0.33 \mathrm{~V} /$ 日 週2-3回 & $0.66 \mathrm{~V} /$ 日 & 週2-3回 & \\
\hline 1 モル塩化力リウム & $10 \mathrm{~mL}$ & $0.25 \mathrm{~A}$ & $0.5 \mathrm{~A}$ & $0.75 \mathrm{~A}$ & \\
\hline $2 \%$ 塩化カルシウム & $400 \mathrm{mg} / 20 \mathrm{~mL}$ & $0.5 \mathrm{~mL}$ & $1 \mathrm{~mL}$ & $1.5 \mathrm{~mL}$ & \\
\hline 塩酸パンコマイシン & $0.5 \mathrm{~g}$ & $0.4 \mathrm{~V} /$ 日 分2-4 & $0.8 \mathrm{~V} /$ 日 & $1.2 \mathrm{~V} /$ 日 & \\
\hline \multirow[t]{2}{*}{ 塩酸モルヒネ注 } & $10 \mathrm{mg}$ & $0.05 \mathrm{~A} /$ 回 & $0.1 \mathrm{~A} /$ 回 & $0.15 \mathrm{~A} /$ 回 & \multirow{2}{*}{$\begin{array}{l}0.02 \mathrm{~A} / \mathrm{kg} / \text { 回 } \\
0.002 \mathrm{~A} / \mathrm{kg} / \mathrm{hr}\end{array}$} \\
\hline & & $0.05 \mathrm{mg} / \mathrm{hr}(0.12 \mathrm{~A} /$ 日 $)$ & $0.1 \mathrm{mg} / \mathrm{hr}(0.24 \mathrm{~A} /$ 日 $)$ & $0.15 \mathrm{mg} / \mathrm{hr}(0.36 \mathrm{~A} /$ 日) & \\
\hline ガスター注射用 & $20 \mathrm{mg}$ & 1日1-2回 & 1日1-2回 & 1日1-2回 & \\
\hline カルチコール注射液 & $850 \mathrm{mg} / 10 \mathrm{~mL}$ & $0.25 \mathrm{~A} /$ 回 & $0.5 \mathrm{~A} /$ 回 & $0.75 \mathrm{~A} /$ 回 & \\
\hline カルベニン点滴用 & $0.5 \mathrm{~g}$ & 1V/日 & $2 \mathrm{~V} / \mathrm{B}$ & $3 \mathrm{~V} / \mathrm{B}$ & $0.2 \mathrm{~V} / \mathrm{kg} /$ 日 \\
\hline キシロカイン & & $\begin{array}{l}5 \mathrm{mg} / \text { 回 } \\
5 \mathrm{mg} / \mathrm{hr} \quad(120 \mathrm{mg} / \text { 日) }\end{array}$ & $\begin{array}{l}10 \mathrm{mg} / \text { 回 } \\
10 \mathrm{mg} / \mathrm{hr} \quad(240 \mathrm{mg} / \text { 日 })\end{array}$ & $\begin{array}{l}15 \mathrm{mg} / \text { 回 } \\
15 \mathrm{mg} / \mathrm{hr} \quad(360 \mathrm{mg} / \text { 日 })\end{array}$ & $3 \mathrm{mg} / \mathrm{kg} / \mathrm{hr}$ \\
\hline クラフォラン注射用 & $1 \mathrm{~g}$ & $0.5 \mathrm{~V} / \mathrm{日}$ & $1 V /$ 日 & 1. 5V/日 & $0.2 \mathrm{~V} / \mathrm{kg} /$ 日 \\
\hline クリトパン注 & $100 \mathrm{mg}$ & $25 \mu \mathrm{g} / \mathrm{min}(0.36 \mathrm{~A} /$ 日) & $50 \mu \mathrm{g} / \mathrm{min}(0.72 \mathrm{~A} /$ 日) & $75 \mu \mathrm{g} / \mathrm{min}(1.08 \mathrm{~A} /$ 日) & $20 \mu \mathrm{g} / \mathrm{kg} / \mathrm{min}$ \\
\hline ケイテン静注用 & $1 \mathrm{~g}$ & $0.5 \mathrm{~A} / \mathrm{G}$ & 1A/日 & $1.5 \mathrm{~A} / \mathrm{\theta}$ & $0.2 \mathrm{~V} / \mathrm{kg} /$ 日 \\
\hline ケタラール 10 & $200 \mathrm{mg}$ & $0.025 \mathrm{~V} /$ 回 & $0.05 \mathrm{~V} /$ 回 & $0.075 \mathrm{~V} /$ 回 & $0.01 \mathrm{~V} / \mathrm{kg} /$ 回 \\
\hline サンディミュン注射液 & $250 \mathrm{mg}$ & 0.02A/日 持続投与 & 0.04A/日 持続投与 & 0.06A/日 持続投与 & \\
\hline
\end{tabular}


表 2．相互作用簡易チェック表 (一部)

\begin{tabular}{|c|c|c|}
\hline 薬品名 & 特性、注意 & 配合不適製剂 \\
\hline アラセナA & pH 3.3 4. 3、難溶解性 & ソルデム 3 A \\
\hline アレビアチン & 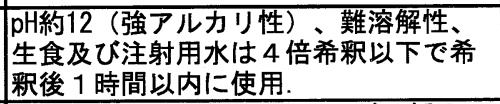 & \\
\hline エレメンミック & $\begin{array}{l}\text { pH 4.5 5.0. 単独のシリンジで採取. } \\
\text { 「情報提供書参照」、 }\end{array}$ & 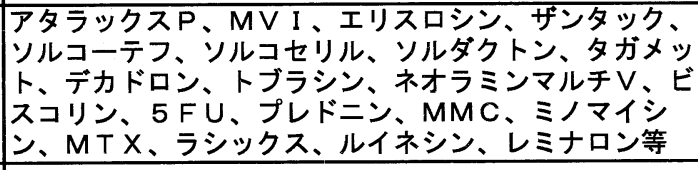 \\
\hline オメプラール & $\begin{array}{l}\text { pH9.5〜11.0. 生食、5\%ブドウ糖液以外 } \\
\text { の輸液、他剂と混合は避ける. 経口 } \\
\text { 投与不可能例のみ適用. }\end{array}$ & \\
\hline ガスター & $\begin{array}{l}\text { pH 4.7〜 5.7 溶解後速やかに使用. 経 } \\
\text { 口投与不可能例のみ適用. }\end{array}$ & 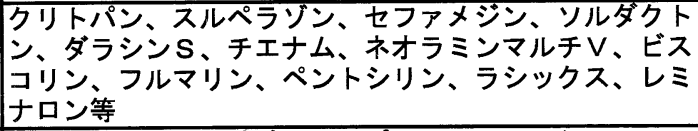 \\
\hline カルチコール & $\begin{array}{l}\text { pH 6.0 8.0、クエン酸塩、炭酸塩、リ } \\
\text { ン酸塩、硫酸塩、酒石酸塩等 }\end{array}$ & $\begin{array}{l}\text { アタラックスP、硫酸アトロピン、エリスロシン、ソル } \\
\text { ダクトン、ネオフィリン、フェシ、、フェノバー等 }\end{array}$ \\
\hline クリトパン & $\begin{array}{l}\text { pH 3.0 5.0、アルカリ性製剂との混合 } \\
\text { 不可 }\end{array}$ & $\begin{array}{l}\text { アシクロビル、アレビアチン、セファメジン、ソルダク } \\
\text { トシ、ファンギゾン、フェジン、ラシックス、ラボナー } \\
\text { ル等 }\end{array}$ \\
\hline ケイツーN & 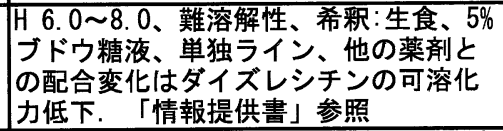 & 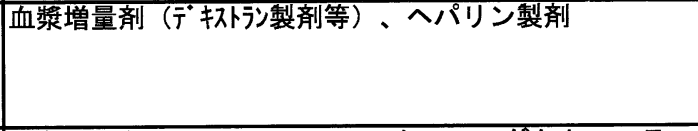 \\
\hline ザンタック & $\begin{array}{l}\text { pH 6.5 7.5. 経口投与不可能例のみ適 } \\
\text { 用. }\end{array}$ & $\begin{array}{l}\text { アタタラックスP、エレメンミック、ソルダクトン、ラ } \\
\text { シックス }\end{array}$ \\
\hline G-CSF & \begin{tabular}{|l} 
フィルター、輸液セットへの吸着注 \\
意、単独ルートが望ましい. 「情報提 \\
供書」参照
\end{tabular} & \\
\hline セルシン & $\begin{array}{l}\text { pH 6.0 7.0、難溶解性、他剂と混合希 } \\
\text { 哷して用いない. 輸液には40倍以上に } \\
\text { 希釈、6 時間以内で使用 }\end{array}$ & $\begin{array}{l}\text { アネキセート、ガストロゼピン、セレネース、ドルミカ } \\
\text { ム、ミラクリッド等 }\end{array}$ \\
\hline ソルダクトン & $\begin{array}{l}\text { pH 9.0〜 10.0 (アルカリ性)、酸性製 } \\
\text { 剂との混合に注意 }\end{array}$ & 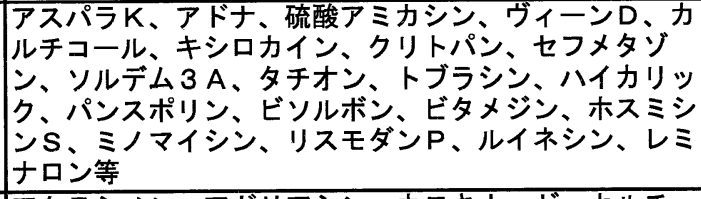 \\
\hline ソルメドロール & $\begin{array}{l}\text { pH 7.0〜8.0、pHの変動等により白沈、 } \\
\text { 輸液等との混合に注意 }\end{array}$ & 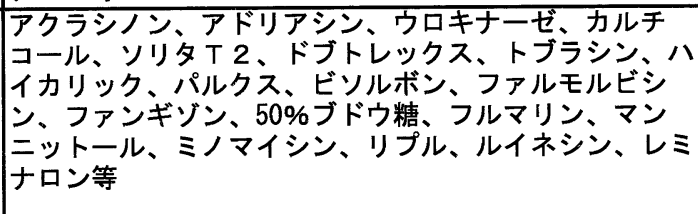 \\
\hline タガメット & $\begin{array}{l}\text { pH 4.5〜6.0. 経口投与不可能例のみ適 } \\
\text { 用. }\end{array}$ & $\begin{array}{l}\text { エレメンミック、スルペラゾン、セファメジン、ソルダ } \\
\text { 吕ン、パンスポリン、ラシックス }\end{array}$ \\
\hline
\end{tabular}

院負担の回避 (薬棛費・保険)の事例を保険薬価に換算し 算出した。

\section{結果および考察}

\section{1. 入院患者数および処方せん枚数}

月ごとの延べ入院患者数と 1 日あたりの平均入院患者 数および注射剤の定時処方せん枚数および 1 日あたりの 平均定時処方せん枚数を，表 3 に示す．測定開始時の 2001年 9 月の 1 日あたりの平均入院患者数は566名で あった．時間の経過とともにわずかに増加傾向を示 し，36力月後の 2004 年 8 月には626名となった。同様 に，月ごとの1日あたりの注射㓮の定時処方せん枚数 は，226枚から296枚となった．1 力月あたりの疑義照会 件数を平均入院患者数と平均定時処方せん枚数による単
回帰式で予測を試みたところ，その重相関係数は 0.176 および 0.120 となった。本結果より，疑義照会件数への 影響は少ないと判断した。

\section{2. 疑義照会}

調査開始後 3 年間における疑義照会件数は，865件で あり，1 力月間の疑義照会件数の最高值は55件，最低值 は 9 件であった。また，4月および10月が他の月よりも 周期的に高くなる傾向を示した。そこで，当院において 研修医や他の病院勤務医師の診療科配置転換の時期にあ たることから配置転換前月 ( 3 月, 9 月) と配置転換月 (4 月，10月)の疑義照会件数をスチューデントの $\mathrm{t}$ 検定に より比較した（図 1 )。配置転換前と配置転換後における 1 カ月あたりの平均疑義照会件数は $20.2 \pm 3.1$ 件および $32.0 \pm 13.0$ 件であった。疑義照会件数は危険率 $10 \%$ 以下 
表 3. 入院患者数抢よび注射剤処方せん枚数，疑義 照会件数の推移

\begin{tabular}{|c|c|c|c|}
\hline 時期 & 延べ患者数／1日 & 処方せん総数／1日 & 疑義照会数 \\
\hline 2001.9 & $16980 / 566$ & $6780 / 226$ & 21 \\
\hline $2001.10 *$ & $17577 / 567$ & $7516 / 242$ & 19 \\
\hline 2001.11 & $17310 / 577$ & $7025 / 234$ & 22 \\
\hline 2001. 12 & $17608 / 568$ & $6692 / 216$ & 22 \\
\hline 2002. 1 & $16864 / 544$ & $6287 / 203$ & 13 \\
\hline 2002.2 & $16296 / 582$ & $6491 / 232$ & 9 \\
\hline 2002. 3 & $17918 / 572$ & $7314 / 236$ & 16 \\
\hline $2002.4 *$ & $16620 / 554$ & $7135 / 238$ & 26 \\
\hline 2002.5 & $16771 / 541$ & $7465 / 241$ & 27 \\
\hline 2002.6 & $17160 / 572$ & $7058 / 235$ & 21 \\
\hline 2002.7 & $17484 / 564$ & $7698 / 248$ & 12 \\
\hline 2002.8 & $17267 / 557$ & $7967 / 257$ & 26 \\
\hline 2002.9 & $16080 / 536$ & $6526 / 218$ & 17 \\
\hline $2002.10 *$ & $17453 / 563$ & $8092 / 261$ & 28 \\
\hline 2002.11 & $17550 / 585$ & $7658 / 255$ & 19 \\
\hline 2002. 12 & $17856 / 576$ & $6371 / 206$ & 16 \\
\hline 2003.1 & $18042 / 582$ & $9043 / 292$ & 24 \\
\hline 2003. 2 & $16772 / 599$ & $8076 / 288$ & 22 \\
\hline 2003. 3 & $18414 / 594$ & $8309 / 268$ & 24 \\
\hline $2003.4 *$ & $17280 / 576$ & $7838 / 261$ & 24 \\
\hline 2003.5 & $18104 / 584$ & $8667 / 280$ & 15 \\
\hline 2003.6 & $17880 / 596$ & $8543 / 285$ & 24 \\
\hline 2003.7 & $18755 / 605$ & $8358 / 270$ & 26 \\
\hline 2003.8 & $18693 / 603$ & $8010 / 258$ & 20 \\
\hline 2003. 9 & $17370 / 579$ & $7847 / 262$ & 21 \\
\hline $2003.10 *$ & $18786 / 606$ & $9083 / 293$ & 55 \\
\hline 2003.11 & $18000 / 600$ & $6958 / 232$ & 23 \\
\hline 2003. 12 & $18352 / 592$ & $7329 / 236$ & 35 \\
\hline 2004. 1 & $19561 / 631$ & $7455 / 240$ & 38 \\
\hline 2004. 2 & $19082 / 658$ & $7920 / 270$ & 36 \\
\hline 2004. 3 & $20305 / 655$ & $8752 / 282$ & 22 \\
\hline $2004.4 *$ & $19410 / 647$ & $7700 / 257$ & 39 \\
\hline 2004.5 & $19623 / 633$ & $7168 / 231$ & 27 \\
\hline 2004.6 & $19140 / 638$ & $7588 / 245$ & 23 \\
\hline 2004. 7 & $19840 / 640$ & $8627 / 278$ & 22 \\
\hline 2004.8 & $19406 / 626$ & $9166 / 296$ & 23 \\
\hline
\end{tabular}

* : 研修医の配置転換月

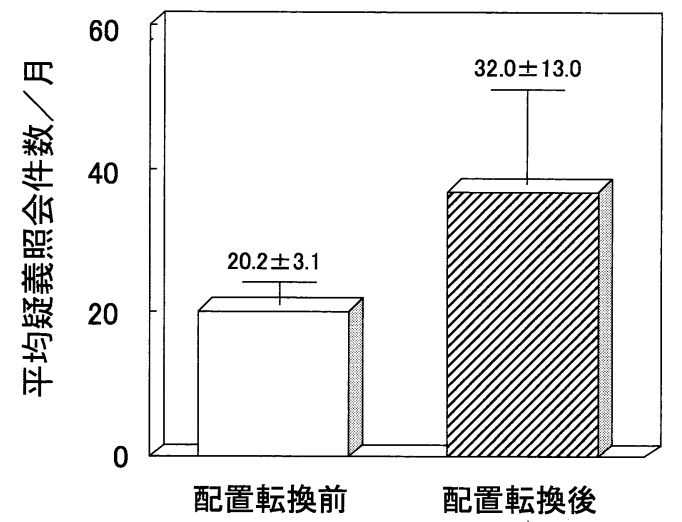

図 1. 研修医の配置転換前後 1 力月における疑義 照会件数の比較

で配置転換による若干の差が観察された。また，配置転 換前の変動係数が15\%であるのに対して配置転換後が $41 \%$ と高い值を示した。これは，他の要因が関与したも のと思われる。これらの結果から，研修医の配置転換前 にあらかじめ注射剤処方入力に関する研修の機会を設け
ることが必要であるといえる。変動要因の解析とその対 応については今後の検討課題と考える.

診療科別の疑義照会件数を，図 2 に示す。上位 5 診療 科は, 消化器病センター (144件，16.6\%), 心臓血管七 ンター (96件，11.1\%)，難病医療センター(82件，9.5 $\%)$ ，血液内科 (66件， $7.6 \%$ )，小児科 (63件，7.3\%)で あり，疑義照会件数は全体の約半数を占めた。また，上 位 5 診療科とその他診療科の病床数に対する総疑義照会

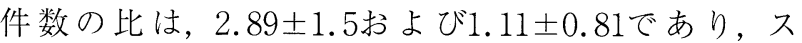
チューデントの $\mathrm{t}$ 検定で危険率 $0.5 \%$ で有意な差がみら れた。以上の結果から，これらの診療科を重点的に対応 することにより，効率的に疑義照会の件数は減少すると 考える。

\section{1）照会内容による分類}

疑義照会の内容による分類と件数を図 3 に示す.

2）投与量

投与量に関する疑義照会件数は326件,全体の約 $37.7 \%$ となり 6 項目中第 1 位であった。この中で重複入力は, 一人の患者に同一処方や類似処方が複数入力された場合 であり，その総数は，223件となりその 3 分の 2 を占め た。この一因として医師の入力ミスが考えられる。過量 投与，過少投与は，添付文書に記載された投与量と大き く異なる場合であり，その総数は93件であった。中で も，投与量が過量であった事例は89件でありその大半を 占めた．当院の注射剤オーダリングシステムの基本が 1 日分ごとの処方が原則である。複数日分の入力は, 複数 日分がまとめて入力された場合である。その総数は 7 件 であり, すべてが退院処方として誤って入力された事例 であった。一方，抗癌剤混合業務の開始に伴い，癌化学 療法実施計画書 (プロトコル)との不一致例が12件みられ た。

小児科の疑義照会件数は63件であり，簡易小児投与量 チェック表の導入前が48件，導入後が15件であった。こ の中で, チェック表導入前後の投与量に関する疑義照会 件数とその割合は，それぞれ13件，27.1\%おょび 6 件，40.0\%であった. 同様に，1 カ月あたりの疑義照会 件数は1.92件および1.36件であった，以上の結果は，本 チェック表の導入により1 カ月あたりの疑義照会件数は 減少した. 本チェック表は, 当院の安全管理委員会が主 体となり医師，薬剤師，看護師が共同で作成したことも あり，注射剤調剂のみならず医師の処方入力時や看護師 の病棟での投与時にも使用されている。本結果から，情 報の共有化がなされた本チェック表の有用性が示された と考える.

3) 用法

用法に関する疑義照会件数は128件となり，疑義照会 全体の $14.8 \%$ を示した. その中で, 用法指示の不一致例 が109件と最も多く，用法に関する疑義照会の $85.2 \%$ を 


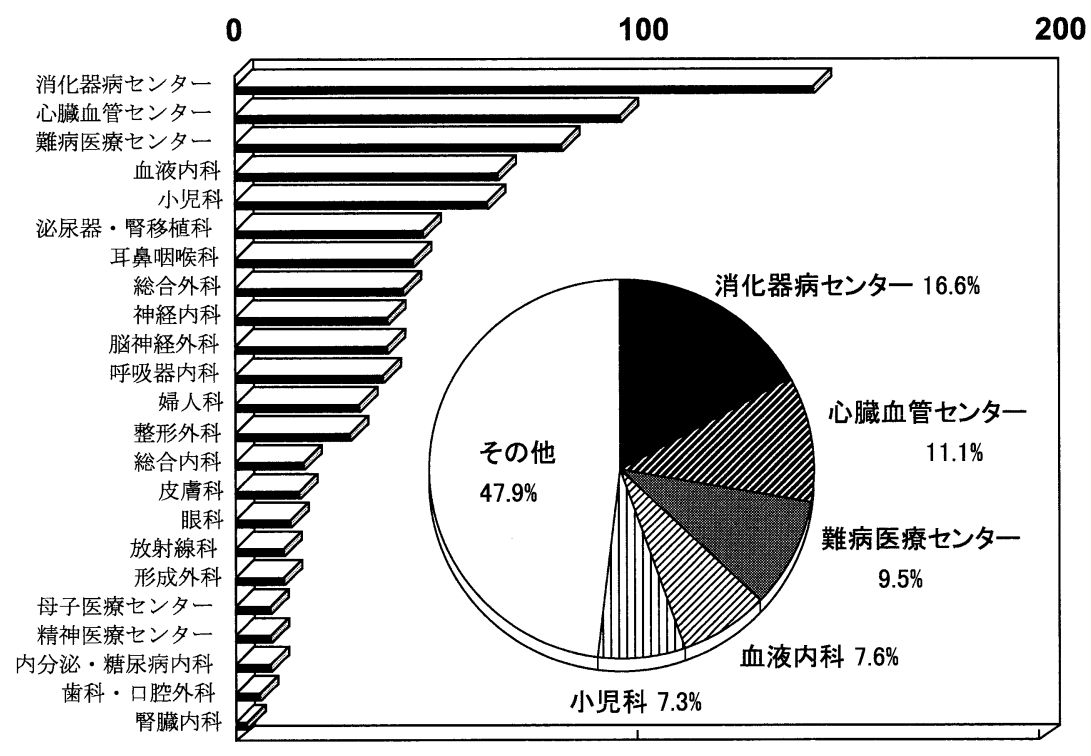

図 2. 各診療科別疑義照会件数とその割合

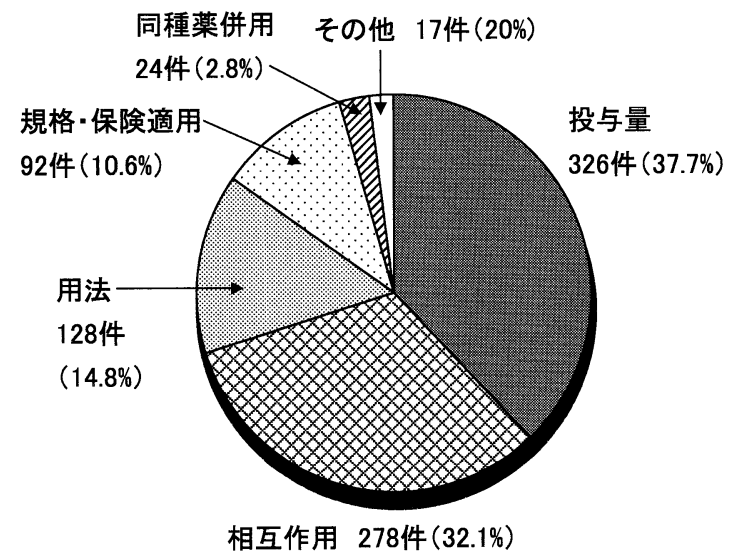

図 3. 内容別疑義照会件数とその割合 (総数 865件)

占めた。このほか注射剤の希釈法に関するもの 5 件, 投 与法に関するもの 3 件, その他11件であった。

\section{4) 相互作用}

相互作用に関する疑義照会件数は278件となり，全体 の約 $32.1 \%$ 占めた. 相互作用を薬理学的相互作用と物 理化学的相互作用に大きく分類したとき, 薬動力学的相 互作用の総数は95件, 物理化学的相互作用は 181 件, そ の他 1 件であった. 薬動力学的相互作用の主な事例とし て「ホスミシン $\mathrm{S}^{\circledR}$ 注」(明治製菓(侏) $)$ の溶解・点滴用に「生 理食塩液」を用いる，「プリンペラン®注」(アステラス 製薬(株) と $\mathrm{H}_{2}$ ブロッカー注を併用するなどであった．前 者は,「ホスミシン $\mathrm{S}^{\circledR}$ 注」がナトリウムを $14.5 \mathrm{mEq} / \mathrm{g}$ 含 有するため, 高ナトリウム血症による諸症状の出現が危 惧される．後者は，2剤の併用により上部消化管の出血 を促す危険性がある。これは添付文書にも記載されてい
る. 物理化学的相互作用の主な事例として,「パンスポ リン®注」(武田薬品工業(株))と「ビスコリン®注」(第一製 薬(株))が同一処方となる場合, 特に $\mathrm{pH}$ の異なる製剤の 混合事例が多くみられた。また，製㶡の混合による物理 的変化としてミセル構造の破壊がある. 高カロリー輸液 用微量元素製剂である「エレメンミック®注」(味の素 ファルマ(株) は, コンドロイチン硫酸の添加によりミセ ル構造を有している。ある製剤との混合により添加剤が 反応してその構造は破壊され, 沈殿を生じる.また, 脂 溶性物質の浮遊, 溶解度が低い薬物の結晶析出などの事 例がみられる．脂溶性であるビタミン $\mathrm{K}_{2}$ を主薬とする 「ケイツー $\mathrm{N}^{\circledR}$ 注」(エーザイ(株))は，精製大豆レシチンの 添加により可溶化されている。ある製剤との混合により 油相が分離して浮遊する。一方, 溶解度の低い薬物を点 滴使用する際には，一定量以上の液量がないと結晶が析 出する場合がある。

代表的な疑義照会事例における照会件数の経時的変化 を図 4 に示す．疑義照会を繰り返し，説明文書を添付す ることにより，その件数は減少する傾向を示した。一 方，入院患者を対象とした抗癌剂の混合業務を開始した ことにより, 抗癌剤に関する疑義照会数は増加する傾向 を示した. 著者らが作成した簡易相互作用表は，頻度が 高い事例をあげたものであり，鑑査者の机上に置いて使 用することが可能であることから，利便性は高いと考え る.

\section{5 ）同種薬の併用}

同種薬の併用に関する疑義照会件数は24件となり, 全 体の約 $2.8 \%$ であった. 中でも同種製剤の併用は 7 件で あり，主な事例として，IVH 処方における 2 種類の総 合ビタミン剂, $\mathrm{H}_{2}$ ブロッカーとプロトンポンプ阻害薬で 


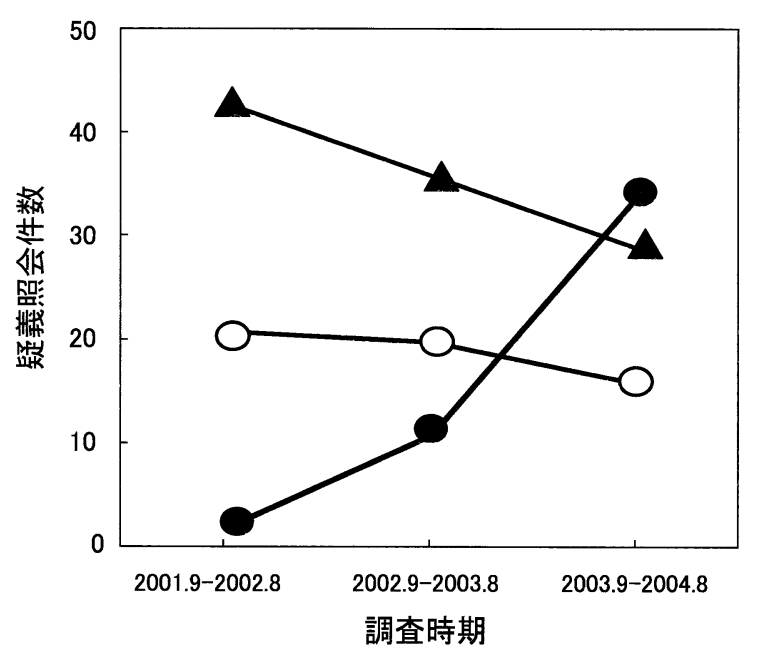

図 4. 代表的な疑義照会例とその件数の経時的推移 一一 ホスミシン $\mathrm{S}{ }^{\circledR}$ 注の溶解液の選択 (生理食塩液は不適)

——エレメンミック®注との配合性 抗覀性腫瘍薬製剂関連

あった．また，複数の同系統抗生物質を併用した事例は 3 件であった。

6 ）規格・保険適用

規格・保険適用に関する疑義照会件数は92件となり， 全体の10.6\%を占めた.その内, 製剤規格の選択が56件, 保険適用不可例が35件，その他が1件であった。 中でも 規格に関する疑義照会は，無駄のない規格を選択するこ とにより，効率の良い薬剤の使用が可能となる.

保険適用不可と考えられる事例は，「ハベカシン®注」 (明治製菓(株) の吸入,「ビソルボン®注」(日本ベーリン ガーインゲルハイム(秼))のネブライザー使用，「エフオー ワイ注(小野薬品工業(株)) (レミナロン注(塩野義製薬 (株))」の DIC 以外への使用，静脈注射例での総合ビ夕ミ ン剂の使用などであった。これらもまた，病院経営に関 わる重要な疑義照会項目であるといえる。

7 ）その他

1）から 5）に分類されない疑義照会件数は17件であ り，主にオーダリングシステムに関する疑義照会，搬送 に関わる内容であった。

\section{3. 得られた成果}

注射剂調剂での疑義照会による得られた成果の延べ数 (921件)の内容を図 5 に示す．その内，薬物療法に関わ る回避効果は746件であった。中でも, 副作用などの有 害事象回避の事例が589件であり, 全体の半数以上を占 めた。また，薬効の減弱を回避した事例は157件であっ た. 以上の結果より，注射剂調剂における疑義照会が， 薬物治療に対して貢献するものと判断した。今後は，有 害事象の回避などの成果を数量化して評価することも必

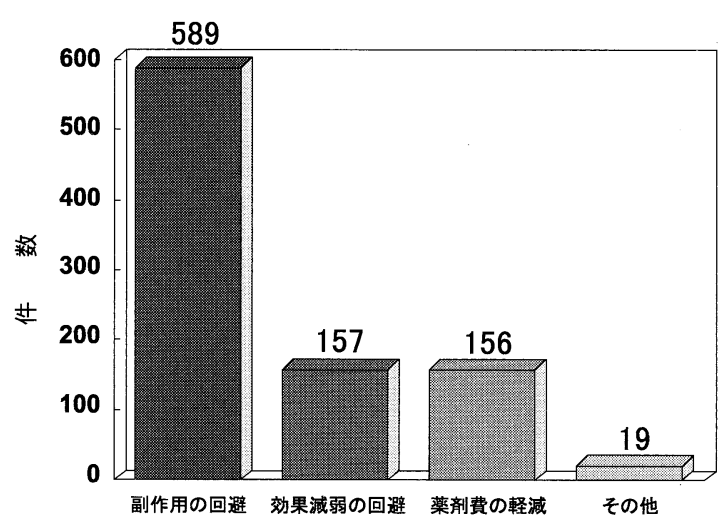

図 5. 疑義照会によって得られた成果 (総延心件数：921件)

要と考える.

一方，薬効や副作用に関するものの他に，疑義照会に よる病院経営や医療費負担への関与が156件であった。 注射剂の重複調製や物理化学的な相互作用による薬剤の 廃棄などを 6 力月間の回避事例100件を保険薬価で算定 したところ，総額は2,449,315円であった。これを元に 1 年間を予測すると約500万円となる。最近，医療経済 学的見地から病院経営に対する薬剤師の関与が求められ ている7,8).

本研究により，注射剤調剤において独自のチェック表 を利用して疑義照会とその対応を行ったことにより，安 全管理のみならず病院経営面での貢献が明らかとなっ た.今後，安全管理面と病院経営面も同時に考慮した注 射剂調剂システムの構築が必要と考える。

謝辞 本研究の実施にあたり，ご指導・ご協力いただいた 山本勝義，三尾良一，吉原隆一諸氏に感謝いたします。

\section{引用文献}

1）日本薬剂師会編，“第十一改訂調剂指針”，薬事日報 社, 東京, 2001, pp. 173-210.

2) 寒河江喜紀, 福井了三，吉岡克巳，近藤克幸，松本 喜良，鈴木敏夫，当院における注射剤オーダリング システムの構築とその評価, 医療薬学, 27, 159-166 (2001).

3）名徳倫明，注射剂によるリスクを回避するための薬 剂師業務の構築一注射剂調剂から患者投与まで一, 医療薬学，31，89-98 (2005).

4) M. Iwata, Y. Takahashi, T. Honda, S. Kaneda, M. Kojima, R. Yoshihara, R. Mio, K. Sakai, K. Yamamoto, Y. Machida, An Automatic Ampoule Dispensing Sysem Improved Injection Dispensing, J. Pharm. Health CareSci., 29, 470-475 (2003).

5) 岩田政則, 縄田修一, 高橋由里, 月見里薰, 吉原隆 一，酒井君子，三尾良一，山本勝義，注射剂適正使 
用のための調剤業務システム $-\mathrm{H}_{2}$ 受容体遮断薬，プ ロトンポンプ阻害薬一, 医療薬学, 29, 593-598 (2003).

6) 山口県病院薬剤師会編, “注射薬調剤鑑査マニュア ル”，エルゼビア・サイエンス, 東京, 2002.
7）守口淑秀，武市佳己，末丸克矢，荒木博陽，病院経 営改善への薬剤師の参画, 医療薬学, 30, 511-517 (2004).

8）庭田聖子, 池田俊也, 臨床薬剤師介入による経済的 効果の算出, 日本病院薬剂師会雑誌, 37, 445-448 (2001). 